\title{
Spectrum of mutations in patients with organic acidurias from Ukraine
}

\author{
O. I. Barvinska1,2, N. V. Olkhovych ${ }^{1}$, T. O. Shkurko ${ }^{1}$, N. G. Gorovenko \\ ${ }^{1}$ National Children's Specialized Hospital Okhmatdyt, Ministry of Health of Ukraine \\ 28/1, Chornovola Str., Kyiv, Ukraine, 01135 \\ 2 P. L. Shupik National medical academy of post-graduate education \\ 9, Dorohozhytska Str., Kyiv, Ukraine, 04112 \\ oiaminska@gmail.com
}

\begin{abstract}
Aim. To identify mutations in patients from Ukraine with glutaric aciduria I, isolated methylmalonic aciduria, and isovaleric aciduria. Methods. Sanger sequencing. Results. We have identified $37.5 \%$ of alleles (3/8) in patients with methylmalonic aciduria, $100 \%$ of alleles $(4 / 4)$ in patients with isovaleric aciduria, $100 \%$ of alleles (4/4) in patients with glutaric aciduria type I. MUT gene mutations in patients from Ukraine are represented by one known N219Y missense mutation p. and a R326G missense rearrangement. Analysis of the $G C D H$ gene in patients from Ukraine revealed three known missense mutations: R383C, G390R and A421V. Rearrangements in the IVD gene of our patients were represented by two novel mutations: 49dupTGTGGCG, S133C, and one known mutation: R53P. Conclusions. The mutations observed in Ukrainian patients with organic acidurias were mostly represented by rare or new rearrangements. These data could be useful for the development of molecular diagnostics of Ukrainian patients with glutaric aciduria I, isolated methylmalonic aciduria, and isovaleric aciduria
\end{abstract}

Keyw or d s: organic acidurias, $M U T, G C D H, I V D$.

\section{Introduction}

Organic acidurias are a subgroup of inborn errors of metabolism which includes more than 33 inherited disorders by SSIEM classification 2011 [1] and are characterized by the cumulative prevalence of 1:7962 live birth [2]. The most prevalent disorders in this group are isolated methylmalonic aciduria (MIM 251000, deficiency of methylmalonyl-CoA mutase
(EC 5.4.99.2)), isovaleric aciduria (MIM 243500 , deficiency of isovaleryl-CoA dehydrogenase (EC1.3.99.10)), propionic aciduria (MIM 606054, deficiency of propionyl-CoA carboxylase (EC 6.4.1.3)), and glutaric aciduria type 1 (MIM 231670, deficiency of glutaryl-CoA-dehydrogenase (EC 1.3.99.7)). Organic acidurias are caused by the deficiency of enzymes and transporters which take part in metabolism of amino acids, carbohydrates

(C) 2018 O. I. Barvinska et al.; Published by the Institute of Molecular Biology and Genetics, NAS of Ukraine on behalf of Biopolymers and Cell. This is an Open Access article distributed under the terms of the Creative Commons Attribution License (http://creativecommons.org/licenses/by/4.0/), which permits unrestricted reuse, distribution, and reproduction in any medium, provided the original work is properly cited 
or lipid intermediates [3]. Such alterations of metabolism lead to some common clinical manifestations such as developmental delay, seizures, lethargy, coma, vomiting, failure to thrive, hepatomegaly, respiratory distress and some unique ones such as dystonic-dyskinetic disorder, macrocephaly in case of GA I, sweaty odor of feet in case of IVA [3-5]. The most common biochemical features are hyperammonemia, metabolic acidosis, ketosis and hypoglycemia. Without treatment these disorders could result in coma or death very quickly. Therefore, early diagnosis is crucial for decreasing a level of disability, mortality and morbidity of patients. In all developed countries the majority of organic acidurias are detected within the newborn screening by tandem mass spectrometry of acylcarnitines in dry blood spots [6]. The diagnosis is confirmed by gas chromatography, mass spectrometry or molecular genetic analysis.

Glutaric aciduria I (GA I) and isovaleric aciduria (IVA) are monogenic autosomal recessive inherited disorders, caused by mutations in genes $G C D H$ (mapped to 19p13.2, includes 12 exons) and IVD (mapped to 15q.14-15, includes 12 exons) respectively [4, 5]. Noteworthy, methylmalonic aciduria (MMA) is a big heterogenous group of inherited disorders which are remarkable for elevation of methylmalonic acid in biological fluids. In terms of biochemical features these disorders are divided into two groups - isolated MMA and combined MMA. Isolated MMA is a clinical condition which could be caused by mutations in such genes as $M U T, M M A A, M M A B$ and $M C E E$, while combined MMA manifests in complex with homocystinuria/homocysteinemia and is caused by mutations in the genes
MMACHC, MMADHC, LMBRD1, ABCB4, $\mathrm{HCFCl}$ [7]. The isolated MMA is a more prevalent disorder than the combined one and $60 \%$ of mutations are detected in the MUT gene (mapped to 6p.12.3, consists of 13 exons) [8]. The current mutation database HGMD Professional 2017.4 describes $361 \mathrm{mu}-$ tations in the MUT gene, 87 rearrangements in the IVD gene, and 208 the in $G C D H$ gene. The absence of highly predominant mutations in the genes MUT, IVD and GCDH and the need to define and distinguish different types of MMA stipulate the use of sequencing as a common method of confirming MMA, IVA and GA I.

\section{Aim}

To investigate a disease-causing mutations spectrum in patients with organic acidurias from Ukraine.

\section{Materials and Methods}

This study included 8 patients (4 males and 4 females) aged from 10 days to 3 years. These individuals were selected for organic aciduria diagnosis confirmation by selective screening of inborn errors of fatty acid and amino acid metabolism (2011-2016). All selected patients with suspected isolated methylmalonic aciduria, glutaric aciduria type I or isovaleric aciduria had elevations of typical acylcarnitines in dry blood spots and organic acids in urine. All parents gave their written informed consent on these investigations. The study was approved by the Committee of Bioethics of NSCH "OKhMATDYT".

Dry blood spots were collected on Whatman ${ }^{\mathrm{TM}} \mathrm{N} 903$ specimen collection papers and dried according to all requirements. 
Genomic DNA was extracted from dry blood spots with NEOGENE reagents kit (Ukraine) according to the manufacturer's protocol.

The exons and flanking intronic regions of the $M U T, I V D$ and $G C D H$ genes were amplified by the polymerase chain reaction (PCR) from genomic DNA in SimpliAmp ${ }^{\text {TM }}$ Thermal Cycler (Thermo Fisher Scientific) with the amplification kit GenPak $\AA P C R C$ ore NEOGENE (Ukraine) and primers developed with Primer3 software. The primers are presented in Table 1.
The visualization of PCR products was performed with capillary electrophoresis on MCE-202 MultiNA Shimadzu (Japan) using DNA 500 Shimadzu kit (Japan), 1000 Shimadzu kit (Japan) and molecular weight marker 25 bp DNA Ladder Invitrogen by Life Technologies (USA), and dye SYBR ${ }^{\circledR}$ Gold Molecular probes by Life Technologies (USA).

The PCR products were sequenced directly using forward and reverse primers on genetic analyzer ABI 3130 by Applied Biosystems (USA). The preparation of samples to sequenc-

Table 1. Primers for exons and flanking intronic regions of genes $G C D H, I V D$ and $M U T$

\begin{tabular}{|c|c|c|c|c|c|}
\hline \multicolumn{2}{|r|}{ GCDH gene } & \multicolumn{2}{|r|}{ MUT gene } & \multicolumn{2}{|r|}{ IVD gene } \\
\hline Exon & Primers & Exon & Primers & Exon & Primers \\
\hline $2-3$ & $\begin{array}{l}\text { F: ggccggattctaggaggaac } \\
\text { R: cttagtgcctctgaccctgg }\end{array}$ & 2 & $\begin{array}{l}\text { F: aggaagcagaaaaggggaaga } \\
\text { R: cgtgcatgtgttgttttctttca }\end{array}$ & 1 & $\begin{array}{l}\text { F: cacggttgattggctcgg } \\
\text { R: tgtccacggtctcaaatct }\end{array}$ \\
\hline $4-5$ & $\begin{array}{l}\text { F: gtcacctgatcagtctcgct } \\
\text { R: cagtgagccaagatcgtgc }\end{array}$ & 3 & $\begin{array}{l}\text { F: gttggttttgacatgtatgagca } \\
\text { R: cctgcaagtaacgacagaaca }\end{array}$ & $2-3$ & $\begin{array}{l}\text { F: tcaagctgtctaggctgaaga } \\
\text { R: cacaggtccaaagatgcagt }\end{array}$ \\
\hline 6 & $\begin{array}{l}\text { F: accctctgaaagtggctgtg } \\
\text { R: gatcagatctccaggtgaagc }\end{array}$ & 4 & $\begin{array}{l}\text { F: ggtacagtcctgatgatggttc } \\
\text { R: ttcaacagcacagtggatcc }\end{array}$ & 4 & $\begin{array}{l}\text { F: taagcaggtctgtggcatca } \\
\text { R: atccatggccecttcctaac }\end{array}$ \\
\hline $7-8$ & $\begin{array}{l}\text { F: cctgccttggectcctaaa } \\
\text { R: cgagtccggctgagtaagaa }\end{array}$ & 5 & $\begin{array}{l}\text { F: cataaatgtacgtgcactgatct } \\
\text { R: gcactacagggaagctagga }\end{array}$ & $5-6$ & $\begin{array}{l}\text { F: ctttaccgacaccetggtct } \\
\text { R: cttttggtcaccetccttgc }\end{array}$ \\
\hline 9 & $\begin{array}{l}\text { F: ggactgtgtgcaaaccgag } \\
\text { R: ccacagctgctcagaagga }\end{array}$ & 6 & $\begin{array}{l}\text { F: aaacactgaactctgactcttct } \\
\text { R: actgctgttctttgtatgagct }\end{array}$ & 7 & $\begin{array}{l}\text { F: gggagcatgggactaggatg } \\
\text { R: cacatgtcactgaagcgcta }\end{array}$ \\
\hline 10 & $\begin{array}{l}\text { F: agtgacgtccttctgagcag } \\
\text { R: catcaaggacaagagggacag }\end{array}$ & 7 & $\begin{array}{l}\text { F: tcccaagacttaagaggttttgt } \\
\text { R: tatgcttgcctgtgtgcatc }\end{array}$ & 8 & $\begin{array}{l}\text { F: agctccacttctgactggaa } \\
\text { R: tcctcaggccttttgtctgt }\end{array}$ \\
\hline 11 & $\begin{array}{l}\text { F: ctgctgtccctcttgtcctt } \\
\text { R: ccacagtccccatgtgagta }\end{array}$ & 8 & $\begin{array}{l}\text { F: tctactttcctctcacacccc } \\
\text { R: tcctgagcaagtttctcaatgc }\end{array}$ & 9 & $\begin{array}{l}\text { F: ccgtaactgtggcaagactt } \\
\text { R: ctgcatgctgaggaagactg }\end{array}$ \\
\hline 12 & $\begin{array}{l}\text { F: agcattcaccatctctgttgg } \\
\text { R: aggaacacatctgaacgacttc }\end{array}$ & 9 & $\begin{array}{l}\text { F: acttgggaaggtcagcactatta } \\
\text { R: cctcagccacagtaaaatacaca }\end{array}$ & $10-11$ & $\begin{array}{l}\text { F: ccccatctccatcatcctga } \\
\text { R: aggctggtcttgaactcctg }\end{array}$ \\
\hline & & 10 & $\begin{array}{l}\text { F: aagagaattggatgcataaaggc } \\
\text { R: tctgtttgacatgagaaactcct }\end{array}$ & 12 & $\begin{array}{l}\text { F: ccctccctcttgctaccttt } \\
\text { R: ttgggagctgttgtggagaa }\end{array}$ \\
\hline & & 11 & $\begin{array}{l}\text { F: cctgcacattaaccectgaat } \\
\text { R: agtcagtggctacataccagt }\end{array}$ & & \\
\hline & & 12 & $\begin{array}{l}\text { F: ctcccattctgtaggttatctgt } \\
\text { R: agcataggttactggtttgca }\end{array}$ & & \\
\hline & & 13 & $\begin{array}{l}\text { F: agccccaaatgccagtagta } \\
\text { R: acaccaggcctataagtaaggt }\end{array}$ & & \\
\hline
\end{tabular}

F -forward, R- reverse 
ing and analysis was performed with BigDye Terminator v3.1 cycle sequencing kit by Applied Biosystems (USA), BigDye XTerminator Purification Kit by Applied Biosystems (USA), PCR clean up Gel extraction by Macherey-Nagel (Germany), according to the protocol of the manufacturer.

The assessment of pathogenicity of novel missense mutations was verified with Mutation Taster, Polyphen2, Provean software. Nucleotide sequence changes which result in frameshift were considered pathogenic. The prediction of the effect of novel missense mutations on the structure of protein was made with DeepView4.1 software, the modelling involved the use of a crystallographic structure of human methylmalonyl-CoA mutase PDB ID: 2XIJ previously reported by Froese et al. [9] and human isovaleryl-CoA dehydrogenase PDB ID: 1IVH reported by Tifanny et al. [10]. The analysis of mutations was performed using the normal human MUT (NM_000255.3), IVD (NM_002225.3), GCDH (NM_000159.3) sequences as a reference. The nomenclature of mutations was based on coding sequences according to the standards of the Human Genome Variation Society [11].

\section{Results and Discussion}

The sequencing of exons and intron flanking regions of the MUT, GCDH, IVD genes was performed to confirm the diagnosis of isolated methylmalonic aciduria in 4 patients, glutaric aciduria type $I$ in 2 patients and isovaleric aciduria in 2 patients with a specific profile of elevated acylcarnitines in dry blood spots and organic acids in urine.

According to the gene MUT sequence, two different missense mutations in this gene were identified in 2 patients with suspected isolated type of MMA. Patient 1 carried mutation in 3 exon p. N219Y, c.655 A > T in homozygous state (Table 2). This rearrangement has already been described in the HGMD database and is considered to be a frequent mutation, as its presence in 25 alleles out of 302 in Caucasian population was previously published [8].

Patient 2 had a missense mutation in exon 5 of the $M U T$ gene p. R326G, c. $976 \mathrm{~A}>\mathrm{G}$ in heterozygous state which has not been added to HGMD database yet (Fig. 1A) (Table 2). The analysis of this novel missense mutation with Mutation Taster, PolyPhen2 and Provean Predictor software showed that it had a pathogenic effect (Table 3). The 3D model of methylmalonyl-CoA mutase (MCM) revealed that the replacement of positively charged large amino acid Arg with a small neutral amino acid Gly in the $326^{\text {th }}$ position causes breaking of 4 hydrogen bonds, which Arg326 creates with Thr92, Phe91, Gly380 and Ala330 in the $\mathrm{N}$-terminal domain (Fig. 1B). Consequently, such alterations result in the tertiary conformation changes of methylmalonyl-CoA mutase that likely affect the protein function.

The mutation in the second allele of Patient 2 was not detected in any exon from 2 to 13 and its intronic flanking regions. The only additional findings in Patient 2 were three polymorphisms p. K212K, p. R532H, p. I671V in homozygous state. No mutations were found in exons 2-13 with flanking regions of introns of the MUT gene in two other patients with suspected MMA. In these two patients it is necessary to search for mutations in regulatory regions or introns of the $M U T$ gene or other genes $M M A A, M M A B, M C E E$ which are responsible for other types of isolated MMA [7]. 
Table 2. Mutations in patients with organic acidurias

\begin{tabular}{|c|c|c|c|c|c|c|c|}
\hline \multirow{2}{*}{$\begin{array}{l}\text { Patient } \\
\text { No }\end{array}$} & \multirow{2}{*}{ Diagnosis } & \multirow{2}{*}{ Gene } & \multicolumn{4}{|c|}{ Genotype } & \multirow{2}{*}{$\begin{array}{l}\text { Reported for the first } \\
\text { time }\end{array}$} \\
\hline & & & Exon & Allele 1 & Exon & Allele 2 & \\
\hline 1 & $\begin{array}{l}\text { Methylmalonic } \\
\text { aciduria }\end{array}$ & $M U T$ & 3 & $\begin{array}{l}\text { p. N219Y, } \\
\text { c. } 655 \mathrm{~A}>\mathrm{T}\end{array}$ & 3 & $\begin{array}{l}\text { p. N219Y, } \\
\text { c. } 655 \mathrm{~A}>\mathrm{T}\end{array}$ & Aquaviva [12] \\
\hline 2 & $\begin{array}{l}\text { Methylmalonic } \\
\text { aciduria }\end{array}$ & $M U T$ & 5 & $\begin{array}{l}\text { p. } \mathrm{R} 326 \mathrm{G}, \\
\text { c. } 976 \mathrm{~A}>\mathrm{G}\end{array}$ & NA & NA & $\begin{array}{l}\text { Submitted by GeneX } \\
\text { in Ensemble }\end{array}$ \\
\hline 3 & $\begin{array}{l}\text { Glutaric } \\
\text { Aciduria I }\end{array}$ & $G C D H$ & 10 & $\begin{array}{l}\text { p. R383C, } \\
\text { c. } 1147 \mathrm{C}>\mathrm{T}\end{array}$ & 10 & $\begin{array}{l}\text { p. } \mathrm{R} 383 \mathrm{C}, \\
\text { c. } 1147 \mathrm{C}>\mathrm{T}\end{array}$ & Goodman [13] \\
\hline 4 & $\begin{array}{l}\text { Glutaric } \\
\text { Aciduria I }\end{array}$ & $G C D H$ & 11 & $\begin{array}{l}\text { p. G390R, } \\
\text { c. } 1168 \mathrm{G}>\mathrm{C}\end{array}$ & 12 & $\begin{array}{l}\text { p. } \mathrm{A} 421 \mathrm{~V}, \\
\text { c. } 1262 \mathrm{C}>\mathrm{T}\end{array}$ & $\begin{array}{l}\text { Anikster [14], Biery } \\
{[15]}\end{array}$ \\
\hline 5 & $\begin{array}{l}\text { Isovaleric } \\
\text { aciduria }\end{array}$ & $I V D$ & 1 & c.49dupTGTGGCG & 2 & $\begin{array}{l}\text { p. } R 53 P, \\
\text { c. } 158 \mathrm{G}>\mathrm{C}\end{array}$ & $\begin{array}{l}\text { This study, } \\
\text { Mohsen [16] }\end{array}$ \\
\hline 6 & $\begin{array}{l}\text { Isovaleric } \\
\text { aciduria }\end{array}$ & $I V D$ & 4 & $\begin{array}{l}\text { p. S133C, } \\
\text { c.398 C > G }\end{array}$ & 4 & $\begin{array}{l}\text { p. } S 133 \mathrm{C}, \\
\text { c. } 398 \mathrm{C}>\mathrm{G}\end{array}$ & This study \\
\hline
\end{tabular}

$\mathrm{NA}$ - not available

The sequence of the GCDH gene, performed in order to confirm the diagnosis of glutaric aciduria type I in Patient 3, detected missense rearrangement p. $\mathrm{R} 383 \mathrm{C}$, c. $1147 \mathrm{C}>\mathrm{T}$ in homozygous state (Table 2). This mutation is considered to be rare, for example, in Spanish population it was present in one allele out of 70 and in 3 alleles out of 38 in Japanese population [5, 17]. The diagnosis of glutaric aciduria type I was also confirmed in Patient 4 with the identification of two known missense mutations p. G390R, c. $1168 \mathrm{G}>\mathrm{C}-\mathrm{a}$ rare variant in Caucasian population, and p. A421 V, c. $1262 \mathrm{C}>\mathrm{T}$ - prevalent in Old Order Amish population [14, 15, 18].

The sequencing of the IVD gene in Patient 5 with suspected isovaleric aciduria revealed a known mutation p. R53P, c. $158 \mathrm{G}>\mathrm{C}$ in heterozygous state (Table 2). Previously this mutation was reported in two alleles out of 16 in the USA studies and in 5 alleles out of 46 in Turkish population [16, 19]. A novel duplication of 7 nucleotides - c.49dupTGTGGCG (Table 2) was detected in the second allele of Patient 5 (Fig. 2A). This mutation causes a frameshift in exon 1, changing amino acid sequence and resulting in crucial alteration of tertiary structure of isovaleryl-CoA dehydrogenase with the loss of all cofactor and substrate binding sites. Such a truncated and changed protein could not perform its functions. The analysis of the IVD gene of Patient 6 revealed missense rearrangement p. S133C,

Table 3. Description and characteristics of new mutations in patients with organic acidurias

\begin{tabular}{|c|c|c|c|}
\hline New mutation & Mutation Taster & Polyphen2 & Provean Predictor \\
\hline p. R326G in exon 5 of $M U T$ gene & Disease causing & Probably damaging score of 1.000 & $\begin{array}{l}\text { Deleterious } \\
-6.991\end{array}$ \\
\hline p. $\mathrm{S} 133 \mathrm{C}$ in exon 4 of $I V D$ gene & Disease causing & Probably damaging score of 1.000 & $\begin{array}{l}\text { Deleterious } \\
-4.698\end{array}$ \\
\hline
\end{tabular}


Fig. 1. $A$ - Image of MUT gene sequence of Patient 2 with rearrangement c.976 A > G in heterozygous state. $B$ - Fragments of three-dimensional models of human wild-type MCM (green amino acid residue) and MCM with mutation p. R326G (red amino acid residue).

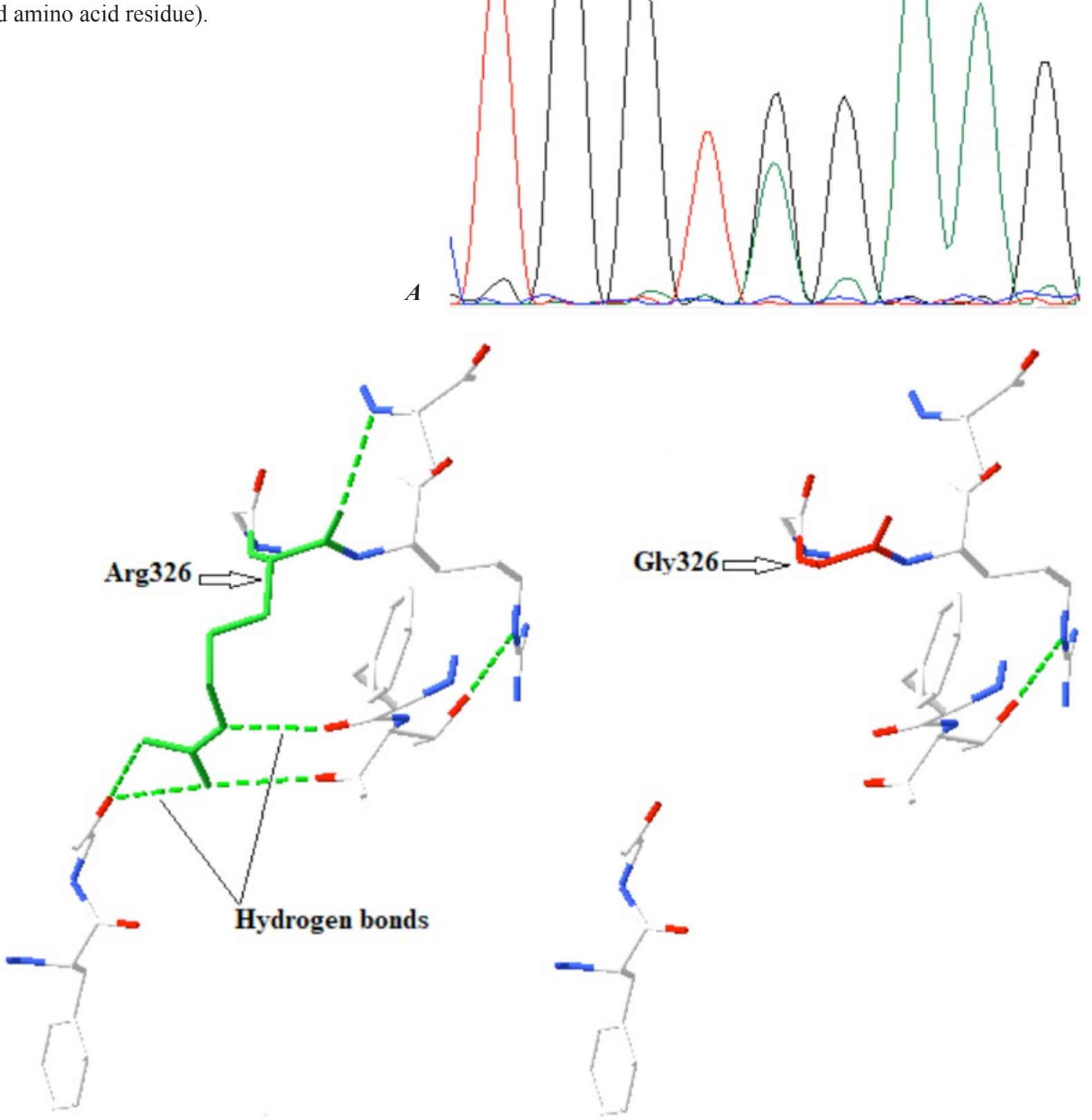


A
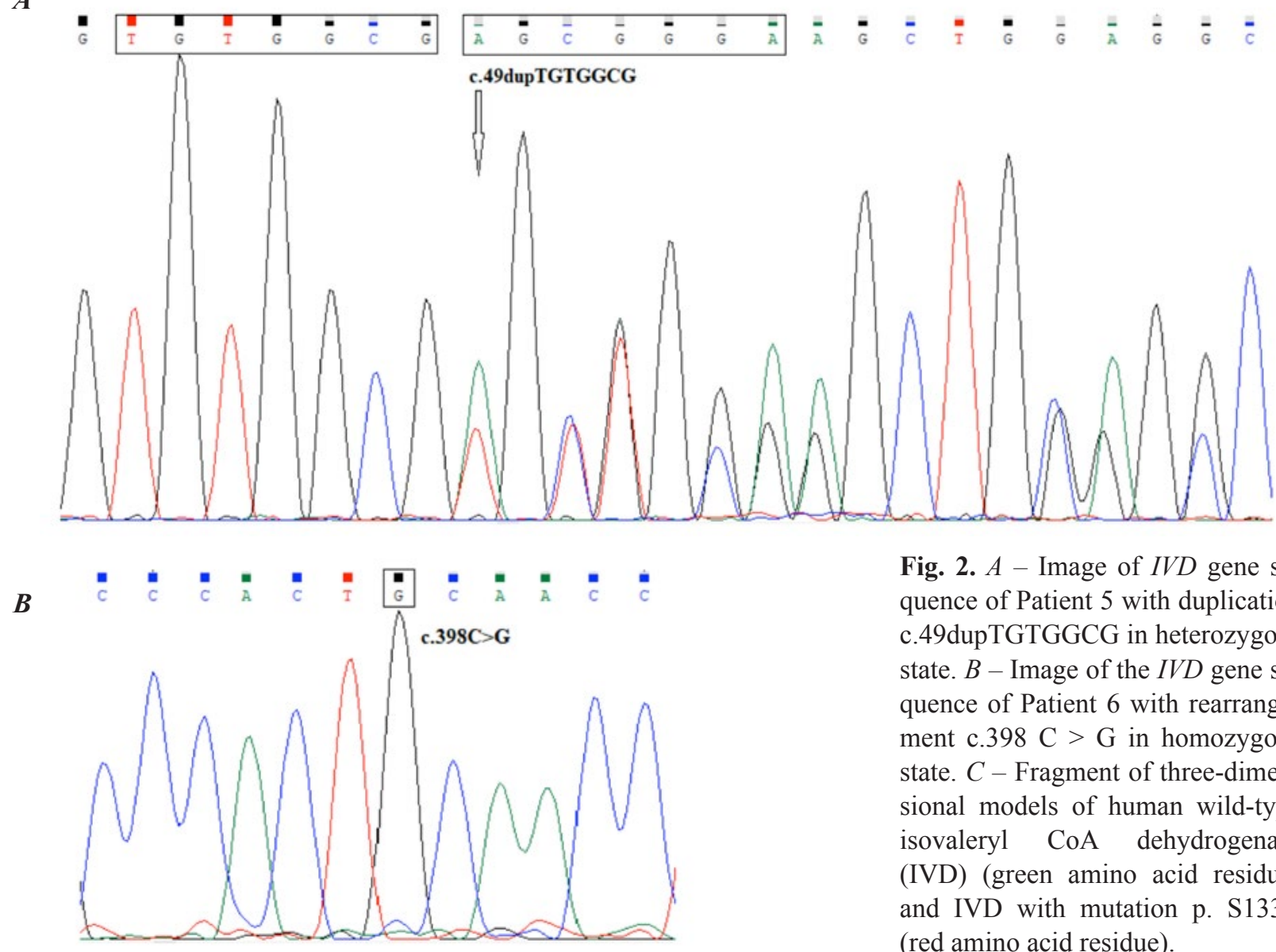

Fig. 2. $A$ - Image of IVD gene sequence of Patient 5 with duplication c.49dupTGTGGCG in heterozygous state. $B$ - Image of the IVD gene sequence of Patient 6 with rearrangement c.398 $\mathrm{C}>\mathrm{G}$ in homozygous state. $C$ - Fragment of three-dimensional models of human wild-type isovaleryl $\mathrm{CoA}$ dehydrogenase (IVD) (green amino acid residue) and IVD with mutation p. S133C (red amino acid residue).

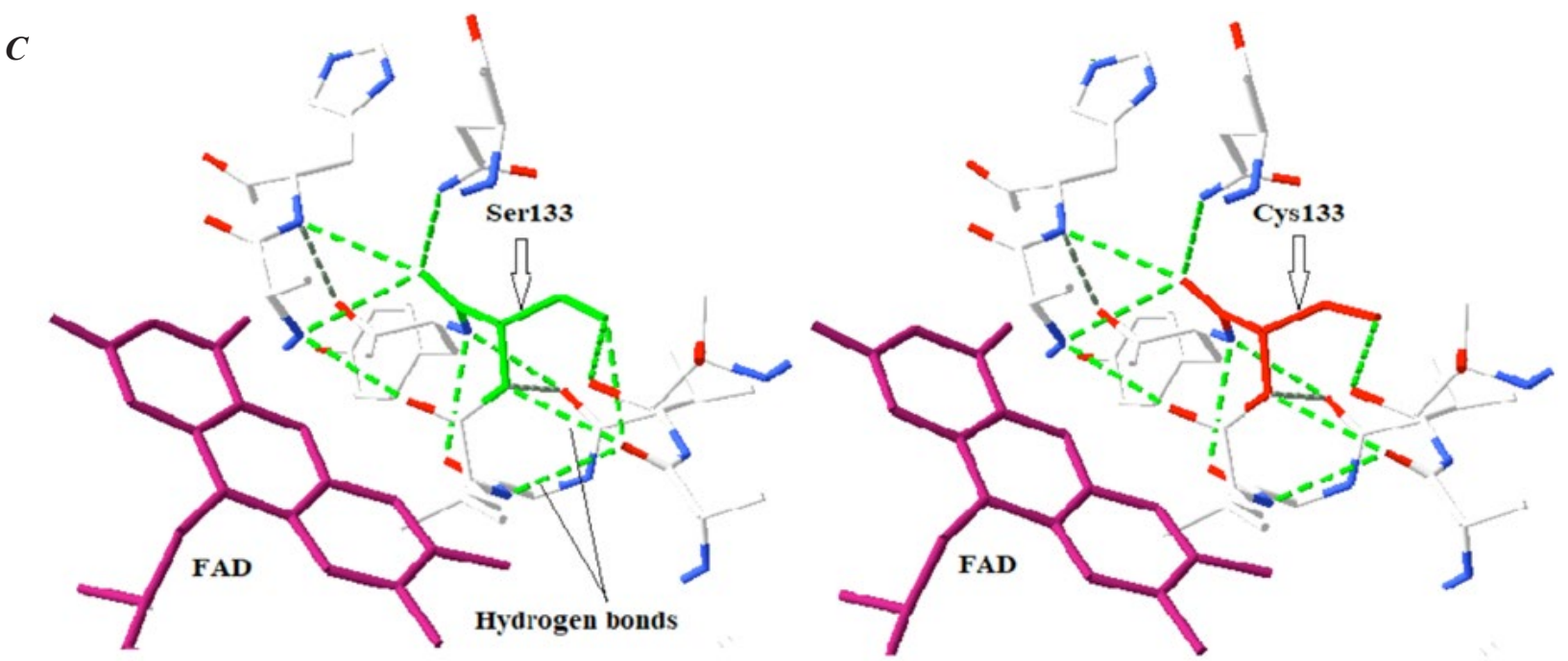


c.398 $\mathrm{C}>\mathrm{G}$ in homozygous state (Table 2) (Fig. 2B). This mutation has not been described in mutation database HGMD yet. The analysis of this rearrangement by Mutation Taster, Polyphen2, Provean software predicted it as the disease-causing one (Table 3). This mutation causes a change of one polar amino acid Serine to another polar amino acid Cysteine in the N-terminal domain of isovaleryl Co-A dehydrogenase (IVD). Such replacement causes breaking of one hydrogen bond which Ser133 creates with Ala129 and lengthens the other which Ser133 creates with Ser256 (Fig. 2C). Also, other hydrogen bonds with Tyr134, Ala136, His137, Val130 remain unchanged. Taking into consideration the fact that this amino acid residue is close to FAD-binding site, such alterations could affect cofactor binding and functional activity of protein.

To sum up, the sequencing of the MUT, IVD and $G C D H$ genes allowed identifying a spectrum of mutations in Ukrainian patients with organic acidurias which is represented by known but rare variants (p. R53P in the IVD gene and p. R383C, p. G390R in the $G C D H$ gene) or novel mutations (p. R326G in the MUT gene, p. S133C and c.49dupTGTGGCG in the IVD gene). The only exceptions were missense mutation p. N219Y in the MUT gene and p. $\mathrm{A} 421 \mathrm{~V}$ in the $G C D H$ gene which are considered to be common variants for Caucasians and Amish population respectively $[7,18]$.

\section{Conclusions}

The sequence analysis of the MUT gene confirmed the diagnosis of classic isolated methylmalonic aciduria in two patients out of 4 suspected ones. In these patients two missense mutations were detected, including one com- monly known mutation $\mathrm{p}$. N219Y (2/8 alleles) and the other undisclosed one $-\mathrm{p}$. R326G (1/8 alleles). According to the results of the $G C D H$ gene sequence, three missense rearrangements p. R383C (2/4 alleles), p. G390R (1/4 alleles), p. A421V (1/4 alleles) were detected in patients with suspected glutaric aciduria type I and the previous diagnosis was confirmed. Two missense mutations - recurrent p. R53P (1/4 alleles) and novel p. S133C (2/4 alleles), and one novel duplication c.49dupTGTGGCG (1/4 alleles) in the IVD gene were revealed in patients with a probable diagnosis of isovaleric aciduria. All new missense mutations were analyzed with Mutation Taster, Polyphen2, Provean Predictor software and were predicted as deleterious ones. Threedimensional modelling of novel missense mutations also revealed alterations in the structure of protein which could affect its functions. In perspective, these data could be used for the development of a molecular genetic diagnostic algorithm for the patients with isolated MMA, GA I and IVA.

\section{REFERENCES}

1. Zschocke J. SSIEM Classification of Inborn Errors of Metabolism. In: Blau N, Duran M, Gibson K, Dionisi Vici C. Eds Physician's Guide to the Diagnosis, Treatment, and Follow-Up of Inherited Metabolic Diseases. Berlin, Heidelberg: "Springer" 2014; 817-30.

2. Sanderson S, Green A, Preece MA, Burton H. The incidence of inherited metabolic disorders in the West Midlands, UK. Arch Dis Child. 2006;91(11): 896-9.

3. Vaidyanathan K, Narayanan MP, Vasudevan DM. Organic acidurias: an updated review. Indian J Clin Biochem. 2011;26(4):319-25.

4. Couce ML, Aldamiz-Echevarría L, Bueno MA, Barros P, Belanger-Quintana A, Blasco J, García-Silva MT, Márquez-Armenteros AM, Vitoria I, Vives I, 
Navarrete R, Fernández-Marmiesse A, Pérez B, Pérez-Cerdá $C$. Genotype and phenotype characterization in a Spanish cohort with isovaleric acidemia. J Hum Genet. 2017;62(3):355-360.

5. Mushimoto Y, Fukuda S, Hasegawa Y, Kobayashi H, Purevsuren J, Li H, Taketani T, Yamaguchi S. Clinical and molecular investigation of 19 Japanese cases of glutaric acidemia type 1. Mol Genet Metab. 2011;102(3):343-8.

6. Therrell BL, Padilla CD, Loeber JG, Kneisser I, Saadallah A, Borrajo GJ, Adams J. Current status of newborn screening worldwide: 2015. Semin Perinatol. 2015;39(3):171-87.

7. Kurkina MV, Baydakova GV, Zakharova EY. Molecular and biochemical characteristics of the isolated methylmalonic aciduria in Russian patients. Med Gen. 2016;15(9):17-28.

8. Forny P, Schnellmann AS, Buerer C, Lutz S, Fowler B, Froese DS, Baumgartner MR. Molecular Genetic Characterization of 151 Mut-Type Methylmalonic Aciduria Patients and Identification of 41 Novel Mutations in MUT. Hum Mutat. 2016;37(8): 745-54.

9. Froese DS, Kochan G, Muniz JR, Wu X, Gileadi C, Ugochukwu E, Krysztofinska E, Gravel RA, Oppermann $U$, Yue $W W$. Structures of the human GTPase MMAA and vitamin B12-dependent methylmalonyl-CoA mutase and insight into their complex formation. J Biol Chem. 2010;285(49):38204-13.

10. Tiffany KA, Roberts DL, Wang M, Paschke R, Mohsen AW, Vockley J, Kim JJ. Structure of human isovaleryl-CoA dehydrogenase at 2.6 A resolution: structural basis for substrate specificity,. Biochemistry. 1997;36(28):8455-64.

11. den Dunnen JT. Sequence Variant Descriptions: HGVS Nomenclature and Mutalyzer. Curr Protoc Hum Genet. 2016;90:7.13.1-7.13.19.

12. Acquaviva C, Benoist JF, Callebaut I, Guffon N, Ogier de Baulny H, Touati G, Aydin A, Porquet D, Elion J. N219Y, a new frequent mutation among mut(degree) forms of methylmalonic acidemia in Caucasian patients. Eur J Hum Genet. 2001;9(8):577-82.

13. Goodman SI, Stein DE, Schlesinger S, Christensen E, Schwartz M, Greenberg CR, Elpeleg ON. Glutaryl-CoA dehydrogenase mutations in glutaric acidemia (type I): review and report of thirty novel mutations. Hum Mutat. 1998;12(3):141-4.

14. Anikster Y, Shaag A, Joseph A, Mandel H, BenZeev B, Christensen E, Elpeleg ON. Glutaric aciduria type $I$ in the Arab and Jewish communities in Israel. Am J Hum Genet. 1996;59(5):1012-8.

15. Biery BJ, Stein DE, Morton DH, Goodman SI. Gene structure and mutations of glutaryl-coenzyme A dehydrogenase: impaired association of enzyme subunits that is due to an A421V substitution causes glutaric acidemia type I in the Amish. Am J Hum Genet. 1996;59(5):1006-11.

16. Mohsen AW, Anderson BD, Volchenboum SL, Battaile KP, Tiffany K, Roberts D, Kim JJ, Vockley J. Characterization of molecular defects in isovalerylCoA dehydrogenase in patients with isovaleric acidemia. Biochemistry. 1998;37(28):10325-35.

17. Busquets C, Merinero B, Christensen E, Gelpi JL, Campistol J, Pineda M, Fernández-Alvarez E, Prats JM, Sans A, Arteaga R, Martí M, Campos J, MartínezPardo M, Martínez-Bermejo A, Ruiz-Falcó ML, Vaquerizo J, Orozco M, Ugarte M, Coll MJ, Ribes A. GlutarylCoA dehydrogenase deficiency in Spain: evidence of two groups of patients, genetically, and biochemically distinct. Pediatr Res. 2000;48(3):315-22.

18. Fraidakis MJ, Liadinioti C, Stefanis L, Dinopoulos A, Pons R, Papathanassiou M, Garcia-Villoria J, Ribes A. Rare Late-Onset Presentation of Glutaric Aciduria Type I in a 16-Year-Old Woman with a Novel GCDH Mutation. JIMD Rep. 2015;18:85-92.

19. Ozgul RK, Karaca M, Kilic M, Kucuk O, YucelYilmaz D, Unal O, Hismi B, Aliefendioglu D, Sivri S, Tokatli A, Coskun T, Dursun A. Phenotypic and genotypic spectrum of Turkish patients with isovaleric acidemia. Eur J Med Genet. 2014;57(10):596-601.

\section{Спектр мутацій у паціснтів з органічними ацидуріями в Україні}

О. Ю. Барвінська, Н. В. Ольхович, Т. О. Шкурко, Н. Г. Горовенко

Мета. Визначення спектру мутацій у пацієнтів 3 України, що страждають на глутарову ацидурію I типу, ізольовану метилмалонову ацидурію та ізовалеріанову ацидурію. Методи. Сиквенування за Сенгером. Результати. Було виявлено 37,5 \% мутантних алелей 
(три зразки з восьми) у пацієнтів з ізольованою метилмалоновою ацирурією, 100 \% алелей (чотири з чотирьох) у хворих з ізовалеріановою ацидурією, 100 \% алелей (чотири з чотирьох) у пацієнтів з глутаровою ацидурією I типу. Спектр мутацій у гені MUT у пацієнтів в Україні представлений однією відомою місенс мутацією с. N219Y та місенс заміною р. R326G. B peзультаті аналізу сиквенсу гену $G C D H$ у пацієнтів було виявлено три відомі місенс перебудови p. R383C, p. G390R та p. A421V. Мутації в гені IVD у наших пацієнтів були представлені двома новими перебудовами с. 49dupTGTGGCG, p. S133C і однією відомою місенс заміною p. R53P. Висновки. Отримані результати показали, що спектр мутацій у пацієнтів 3 органічними ацидуріями в Україні представлений переважно рідкісними або ж новими перебудовами. Ці дані можуть бути корисними для розробки молекулярногенетичного алгоритму діагностики у хворих з України, що мають глутарову ацидурію I типу, ізольовану метилмалонову ацидурію та ізовалеріанову ацидурію.

Кл юч о в і с л о в а: органічні ацидурії, $M U T, G C D H$, IVD.

\section{Спектр мутаций у пациентов с органическими ацидуриями в Украине}

А. Ю. Барвинская, Н. В. Ольхович, Т. А. Шкурко, Н. Г. Горовенко

Цель. Определение спектра мутаций у пациентов с Украины с глутаровой ацидурией I типа, изолирован- ной метилмалоновой ацидурией и изовалериановой ацидурией. Методы. Сиквенирование за Сэнгером. Результаты. Было выявлено 37,5 \% мутантных аллелей (три образца из восьми) у пациентов с изолированной метилмалоновой ацидурией, $100 \%$ аллелей (четыре из четырех) у больных с изовалериановой ацидурией, 100 \% аллелей (четыре из четырех) у пациентов с глутаровой ацидурией I типа. Спектр мутаций в гене $M U T$ у пациентов с Украины представлен одной известной миссенс мутацией с. N219Y и миссенс заменой $\mathrm{p}$. R326G. В результате анализа сиквенса гена $G C D H$ пациентов из Украины было обнаружено три известные миссенс перестройки p. R383C, p. G390R и p. A421V. Мутации в гене IVD у наших пациентов были представлены двумя новыми перестройками с. 49dupTGTGGCG, p. S133C и одной известной миссенс заменой p. R53P. Выводы. Полученные результаты показали, что спектр мутаций у пациентов с органическими ацидуриями в Украине представлен в большинстве редкими или новыми перестройками. Эти данные могут быть полезными для разработки молекулярно-генетического алгоритма диагностики у больных с глутаровой ацидурией I типа, изолированной метилмалоновой ацидурией, и изовалериановой ацидурией в Украине.

К л ю че в ы е с л о в а: органические ацидурии, $M U T$, GCDH, IVD

Received 02.02.2018 